\title{
Biphasic Calcium Phosphate Bioceramics for Orthopaedic Reconstructions: Clinical Outcomes
}

\author{
Carlos A. Garrido, ${ }^{1,2}$ Sonja E. Lobo, ${ }^{3,4}$ Flávio M. Turíbio, ${ }^{2}$ and Racquel Z. LeGeros ${ }^{4}$ \\ ${ }^{1}$ Department of Orthopaedic Surgery, Hospital São Bento Cardioclinica Ltda., Rua Crucis 50, 30.360-290 Belo Horizonte, \\ Minas Gerais, Brazil \\ ${ }^{2}$ Department of Orthopedic Surgery, Federal University of São Paulo, Rua Borges Lagoa 783, 04038-032 São Paulo, Brazil \\ ${ }^{3}$ Department of Morphology, Federal University of São Paulo, Rua Botucatu 740, 04023-900 São Paulo, Brazil \\ ${ }^{4}$ Department of Biomaterials and Biomimetics, New York University College of Dentistry, 345 East 24th Street, \\ New York, NY 10010, USA \\ Correspondence should be addressed to Racquel Z. LeGeros, rzl1@nyu.edu
}

Received 15 January 2011; Accepted 20 April 2011

Academic Editor: Joo L. Ong

Copyright () 2011 Carlos A. Garrido et al. This is an open access article distributed under the Creative Commons Attribution License, which permits unrestricted use, distribution, and reproduction in any medium, provided the original work is properly cited.

$\mathrm{BCP}$ are considered the most promising biomaterials for bone reconstruction. This study aims at analyzing the outcomes of patients who received BCP as bone substitutes in orthopaedic surgeries. Sixty-six patients were categorized according to the etiology and morphology of the bone defects and received scores after clinical and radiographic evaluations. The final results corresponded to the combination of both parameters and varied from 5 (excellent result) to 2 or lower (poor result). Most of the patients who presented cavitary defects or bone losses due to prosthesis placement or revision, osteotomies, or arthrodesis showed good results, and some of them excellent results. However, patients with segmental defects equal or larger than $3 \mathrm{~cm}$ in length were classified as moderate results. This study established clinical parameters where the BCP alone can successfully support the osteogenic process and where the association with other tissue engineering strategies may be considered.

\section{Background}

Commercial bioactive ceramics used for bone repair include calcium carbonate $\left(\mathrm{CaCO}_{3}\right.$, in aragonite form), calcium sulfate $\left(\mathrm{CaSO}_{4} \cdot 2 \mathrm{H}_{2} \mathrm{O}\right.$, plaster of Paris), calcium phosphates, and bioactive glasses. Calcium phosphate ceramics include beta-tricalcium phosphate $\left[\beta\right.$-TCP, $\left.\mathrm{Ca}_{3}\left(\mathrm{PO}_{4}\right)_{2}\right]$, hydroxyapatite $\left[\mathrm{HA}, \mathrm{Ca}_{10}\left(\mathrm{PO}_{4}\right)_{6}(\mathrm{OH})_{2}\right]$, and biphasic calcium phosphate (BCP) (consisting of an intimate mixture of HA and $\beta$-TCP of varying $\mathrm{HA} / \beta$-TCP ratios).

Unknowingly, the first preclinical application of $\mathrm{BCP}$ was reported by Nery et al. in 1975 using a calcium phosphate they described as "tricalcium phosphate" but was analyzed using X-ray diffraction as a mixture of HA and $\beta$-TCP [1] and, consequently, such a mixture was described as a biphasic calcium phosphate, $\mathrm{BCP}[2,3]$. The elaboration of $\mathrm{BCP}$ was first introduced by LeGeros in 1986 [4]. The efficacy of $\mathrm{BCP}$ was based on the preferential dissolution of the $\beta$-TCP compared to HA, allowing the manipulation of bioactivity or biodegradation by manipulating the HA/ $\beta$-TCP ratio [5]. Concentrated studies on their development and applications were made by Daculsi et al. [6-8].

Thus, through the combination of a balanced rate between a more stable phase (HA) and a more soluble one $(\beta-\mathrm{TCP})$, it was possible to formulate a BCP with a controlled dissolution rate and different mechanical properties [5]. The presence of porosity and a bioactive surface facilitate cell attachment, proliferation, and differentiation and, consequently, provide a more biocompatible, osteoconductive, and in some cases, osteoinductive ceramics, which can favor increased bone formation [6, 7, 9-20]. Indeed these chemical and physical properties, produced by variations of the temperature, $\mathrm{pH}$ and duration of the sintering process, make each biomaterial unique and lead to different tissue responses $[7,10,12,13,16-18]$. Currently the BCP represents the most promising and best alternative for bone reconstructions as they can overcome the shortcomings of the autografts and allografts such as expense, limited supply, additional trauma 
in the case of autografts, and risk of disease transmission in the case of allografts.

The objective of this study is to provide a retrospective evaluation, through the analysis of randomly selected clinical cases, of the long-term efficacy and performance of BCP bioceramics as bone substitutes for the reconstruction of defects with different morphologies and caused by distinct etiologies.

\section{Methods}

2.1. Biphasic Calcium Phosphate (BCP) Bioceramics. The BCP bioceramics (Osteosynt ${ }^{\circledR}$, EINCO Biomaterial Ltda., Belo Horizonte, Minas Gerais, Brazil) used for the reconstruction of the defects in 66 patients is composed of $65 \%$ of HA and $35 \%$ of $\beta$-TCP, with a tolerance of $\pm 5 \%$, and characterized by the presence of intercommunicating microand macroporosity of $<10 \mu \mathrm{m}$ and $>100 \mu \mathrm{m}$, respectively. The two different forms used were the granular form (20-40 mesh and 40-60 mesh) and a prefabricated wedge. The characterization of the crystalline phases of the BCP was performed using X-ray diffraction (XRD) (PhillipsPANalytical PW1710, USA); the presence and sizes of porous were demonstrated by scanning electron microscopy (SEM) (S-3500N, Hitachi).

2.2. Clinical Cases. This study was approved by the Ethics Committees of the Hospital São Bento Cardioclinica S.A. (Belo Horizonte, Minas Gerais, Brazil) and all the subjects participating in the study signed a consent form.

This study is a retrospective evaluation of 66 randomly chosen clinical cases of patients who had undergone orthopaedic surgeries with BCP as bone graft substitute.

These sixty-six patients corresponded to 67 surgical procedures (one patient had bilateral interventions). Thirty seven patients were males and 29 females. One patient was 1 -year old and one, 70-year old. The ages of the other 64 patients ranged between 15 -year and 69-year old with a mean age corresponding to 41.6 years (Table 1 ).

The defects were classified according to the etiology of the lesions and the morphology of the bone defect. Regarding the etiology, the defects were divided into the following: (1) orthopaedics defects (32 patients and 33 defects that corresponded to 33 surgical procedures), comprised of bone defects resulting from elective surgical procedures, such as total hip prosthesis (placement and replacement), osteotomies, and arthrodesis and (2) traumatic defects (34 defects corresponding to 34 surgical procedures), which included noninfected pseudoarthrosis, fractures, and arthrodesis after posttraumatic arthrosis.

Regarding the morphology, the defects were divided into: (1) cavitary bone defects (42 defects) and (2) segmental bone defects (or gap defects) (25 defects). The volume of the cavitary bone defects were not measured due to the irregularity of their shape. The size of segmental bone defects was measured from the X-Ray images, and their largest length was noted.
TABLE 1: Description of age, gender, and affected bone of each patient. The initial diagnosis is described in parenthesis. F: female; M: male.

\begin{tabular}{|c|c|c|c|}
\hline Procedure ID & Age & Gender & Bone \\
\hline 01 & 25 & $\mathrm{~F}$ & Femur (pseudarthrosis) \\
\hline 02 & 50 & M & Hip prosthesis (revision) \\
\hline 03 & 51 & $\mathrm{~F}$ & Femur (pseudarthrosis) \\
\hline 04 & 32 & M & Knee (osteoarthrosis) \\
\hline 05 & 51 & $\mathrm{~F}$ & Tarsus (osteoarthrosis) \\
\hline 06 & 69 & $\mathrm{~F}$ & Ankle (pseudarthrosis) \\
\hline 07 & 53 & M & Hip prosthesis (revision) \\
\hline 08 & 64 & $\mathrm{~F}$ & Hip prosthesis (revision) \\
\hline 09 & 33 & M & Tibia (fracture) \\
\hline 10 & 49 & M & Femur (osteonecrosis) \\
\hline 11 & 46 & M & Calcaneus (fracture) \\
\hline 12 & 20 & M & Femur (osteonecrosis) \\
\hline 13 & 53 & M & Femur (pseudarthrosis) \\
\hline 14 & 34 & M & Radius (pseudarthrosis) \\
\hline 15 & 46 & M & Femur (osteonecrosis) \\
\hline 16 & 37 & M & Ankle (fracture) \\
\hline 17 & 38 & $\mathrm{~F}$ & Tibia (pseudarthrosis) \\
\hline 18 & 41 & $\mathrm{~F}$ & Radius (fracture) \\
\hline 19 & 38 & $\mathrm{~F}$ & Acetabulum (reconstruction) \\
\hline 20 & 16 & $\mathrm{~F}$ & Tibia vara \\
\hline 21 & 35 & $\mathrm{~F}$ & Calcaneus (fracture) \\
\hline 22 & 43 & $\mathrm{~F}$ & Clavicle (pseudarthrosis) \\
\hline 23 & 28 & M & Carpal bone (arthrosis) \\
\hline 24 & 42 & M & Hip prosthesis (revision) \\
\hline 25 & 58 & M & Hip prosthesis (revision) \\
\hline 26 & 27 & M & Femur (pseudarthrosis) \\
\hline 27 & 01 & M & Clavicle (congenital pseudarthrosis) \\
\hline 28 & 65 & $\mathrm{~F}$ & Hip prosthesis (revision) \\
\hline 29 & 50 & M & Hip prosthesis (revision) \\
\hline 30 & 60 & $\mathrm{~F}$ & Hip osteoarthrosis \\
\hline 31 & 36 & M & Humerus (fracture) \\
\hline 32 & 70 & M & Wrist (osteoarthrosis) \\
\hline 33 & 24 & M & Radius (fracture) \\
\hline 34 & 33 & M & Calcaneus (fracture) \\
\hline 35 & 32 & M & Forearm (pseudoarthrosis) \\
\hline 36 & 28 & M & Forearm (pseudarthrosis) \\
\hline 37 & 46 & $\mathrm{~F}$ & Femur (pseudoarthrosis) \\
\hline 38 & 56 & M & Ankle (fracture) \\
\hline 39 & 41 & $\mathrm{~F}$ & Knee (osteoarthrosis) \\
\hline 40 & 44 & $\mathrm{~F}$ & Femur (osteotomy) \\
\hline 41 & 33 & M & Femur (fracture) \\
\hline 42 & 49 & $\mathrm{~F}$ & Ankle (fracture) \\
\hline 43 & 22 & $\mathrm{~F}$ & Femur (pseudoarthrosis) \\
\hline 44 & 34 & $\mathrm{~F}$ & Calcaneus (fracture) \\
\hline 45 & 01 & M & Clavicle (congenital pseudarthrosis) \\
\hline 46 & 60 & $\mathrm{~F}$ & Humerus (pseudarthrosis) \\
\hline 47 & 30 & M & Tibia (pseudarthrosis) \\
\hline 48 & 59 & M & Tibia (pseudarthrosis) \\
\hline
\end{tabular}


TABle 1: Continued.

\begin{tabular}{lccl}
\hline Procedure ID & Age & Gender & Bone \\
\hline 49 & 56 & $\mathrm{M}$ & Radius (fracture) \\
50 & 23 & $\mathrm{~F}$ & Humerus (fracture) \\
51 & 30 & $\mathrm{M}$ & Humerus (pseudarthrosis) \\
52 & 34 & $\mathrm{~F}$ & Ankle (arthrosis) \\
53 & 57 & $\mathrm{~F}$ & Elbow (osteoarthrosis) \\
54 & 33 & $\mathrm{M}$ & Femur (fracture) \\
55 & 59 & $\mathrm{~F}$ & Humerus (pseudarthrosis) \\
56 & 40 & $\mathrm{M}$ & Femur (osteonecrosis) \\
57 & 15 & $\mathrm{~F}$ & Femur (genu valgum) \\
58 & 37 & $\mathrm{M}$ & Tibia (fracture) \\
59 & 64 & $\mathrm{~F}$ & Hip prosthesis (revision) \\
60 & 63 & $\mathrm{M}$ & Tibia (fracture) \\
61 & 21 & $\mathrm{~F}$ & Femur (genu valgum) \\
62 & 19 & $\mathrm{M}$ & Femur (pseudoarthrosis) \\
63 & 46 & $\mathrm{M}$ & Femur (pseudoarthrosis) \\
64 & 38 & $\mathrm{M}$ & Knee (osteoarthrosis) \\
65 & 50 & $\mathrm{~F}$ & Hip prosthesis (revision) \\
66 & 62 & $\mathrm{~F}$ & Hip prosthesis (revision) \\
67 & 38 & $\mathrm{M}$ & Ankle (pseudoarthrosis) \\
\hline
\end{tabular}

2.3. Surgical Procedures. The surgical technique used for the implantation of BCP followed the surgical principles that are equivalent to those required for autografts: curettage and debridation of the wound site until viable bone tissue could be observed and impaction of the bioceramics. The bioceramics was applied directly into the bone defects and no extra volume of the bioceramics was used except for the arthrodesis procedures where the creation of an external bridge between the bone extremities was necessary. External or internal fixation systems (AO/ASIF methods) were used according to the indications for each patient.

In acute traumatic lesions, open reductions were performed, and the defects were immediately filled with the BCP.

Three patients received a combination of autografts and BCP: one presented a pseudoarthrosis of the femur with a gap bone loss of $11 \mathrm{~cm}$ in length, one had a bimalleolar fracture of the ankle (considered a cavitary bone defect), and the other presented a pseudoarthrosis of the tibia, with a bone gap of $4 \mathrm{~cm}$ in length.

2.4. Clinical and Radiographic Evaluation. The classification of the final results was based on clinical and radiographic assessments. For the clinical evaluation, the functional movements of the operated limb, without pain, at the end of the treatment, were measured, and scores ranging from 0 to 3 were given as follows:

score 0: absence of movement of the operated arch or limb,

score 1: increased limitation of movements,

score 2: same range of movement compared to the preoperative analysis, and score 3: normal range of motion of the operated arch or limb.

For the radiographic analysis, the presence or absence of integration and the number of surgical procedures performed until the final outcome were considered. The following scores were given:

score 0: no integration of the bioceramics, independent of the number of surgical procedures;

score 1: more than one surgical procedure was performed in order to observe the bioceramics integration (and bone formation);

score 2: the bioceramics were integrated and the patient healed after the first surgical procedure.

The final results represent the combination of both parameters, clinical + radiographic scores: 0 to 2 (poor results), 3 (moderate results), 4 (good results), and 5 (excellent results).

\section{Results}

The XRD diffraction analysis demonstrated the HA/B-TCP ratio of the BCP (Figure 1), and the SEM images showed the presence of micro- and macroporosities in the three presentation forms of the bioceramics used in this study (Figure 2).

Of the 67 procedures performed, five were classified as excellent results (combined score of 5), fifty seven procedures were classified as good (combined score of 4), and five were classified as moderate (combined score of 3 ).

The defects were classified according to the etiology of the bone loss, that is, orthopedic or traumatic defects, and the morphology of the bone defect, that is, segmental (also called gap defects), or cavitary defects, such as cystic lesions.

In the group classified according to the etiology of the defects, thirty two patients underwent thirty three procedures for bone reconstruction with BCP. These patients had orthopedic bone defects associated with hip or knee prosthesis placement or revisions, osteotomies, and arthrodesis. In this group, complete integration of the $\mathrm{BCP}$ after the first surgical procedure was observed and patients experienced improved or the same range of motion of the operated limb or arch without pain. Thus, thirty procedures were classified as good results (score 4) and three had excellent results (score 5) (Table 2).

Thirty four patients underwent 34 surgical procedures to treat traumatic defects. Two of them had excellent final results (score 5), twenty seven had good final results (score 4 ), and five were classified as moderate results (score 3 ). Four out of the five moderate results required an additional surgery to achieve maximum bone formation in the operated site, and one patient had an increased limitation of the limb movements after the treatment (Table 2).

Regarding the morphology of the bone defect, 24 patients with segmental defects underwent 25 procedures, and 42 patients with cavitary bone defects required 42 procedures. Results of the BCP in repairing cavitary bone defects showed 
TABLE 2: Final results according to the etiology of the bone defects. The number of patients and procedures and the final scores given to patients with orthopaedic and traumatic defects are described. All procedures performed in orthopaedic defects presented good or excellent results. Defects caused by trauma are more suitable to show moderate results.

\begin{tabular}{|c|c|c|c|c|c|}
\hline $\begin{array}{l}\text { Etiology of the } \\
\text { defect }\end{array}$ & $\begin{array}{l}\text { Number of } \\
\text { patients }\end{array}$ & $\begin{array}{l}\text { Total number } \\
\text { of procedures }\end{array}$ & $\begin{array}{c}\text { Number of } \\
\text { procedures with } \\
\text { excellent results } \\
\text { (score 5) }\end{array}$ & $\begin{array}{l}\text { Number of } \\
\text { procedures with } \\
\text { good results } \\
\text { (score } 4)\end{array}$ & $\begin{array}{c}\text { Number of } \\
\text { procedures with } \\
\text { moderate results } \\
(\text { score } 3)\end{array}$ \\
\hline $\begin{array}{l}\text { Orthopedic } \\
\text { defects }\end{array}$ & 32 & 33 & 3 & 30 & 0 \\
\hline $\begin{array}{l}\text { Traumatic } \\
\text { defects }\end{array}$ & 34 & 34 & 2 & 27 & 5 \\
\hline Total & 66 & 67 & 5 & 57 & 5 \\
\hline
\end{tabular}

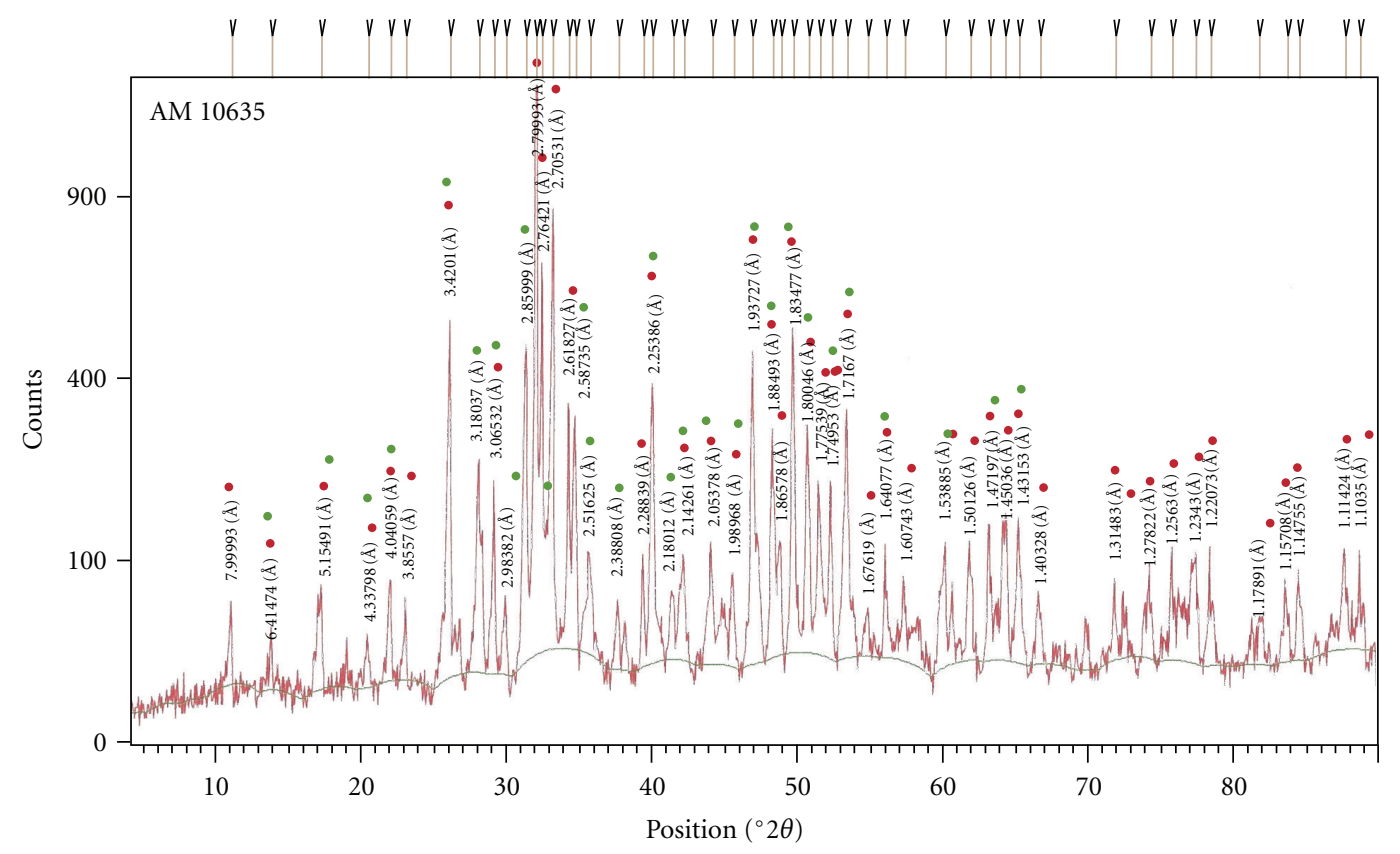

- Hydroxyapatite

- $\beta$-tricalcium phosphate

FIGURE 1: X-Ray diffraction of bioceramics. This analysis shows the crystalline phases of the BCP and the HA/ß-TCP ratio which corresponds to $65 \% / 35 \%$, respectively.

TABle 3: Final results according to the morphology of the bone defects. According to the morphology, most of the defects were classified as cavitary bone loss and presented good results. Moderate results were observed mainly in segmental defects equal or bigger than $3 \mathrm{~cm}$ in length.

\begin{tabular}{|c|c|c|c|c|c|c|}
\hline $\begin{array}{l}\text { Morphology of } \\
\text { the defect }\end{array}$ & $\begin{array}{l}\text { Number of } \\
\text { patients }\end{array}$ & $\begin{array}{l}\text { Total number } \\
\text { of procedures }\end{array}$ & $\begin{array}{l}\text { Lengths of } \\
\text { the defects }\end{array}$ & $\begin{array}{c}\text { Number of } \\
\text { procedures with } \\
\text { excellent results } \\
\text { (score 5) }\end{array}$ & $\begin{array}{l}\text { Number of } \\
\text { procedures with } \\
\text { good results } \\
(\text { score } 4)\end{array}$ & $\begin{array}{c}\text { Number of } \\
\text { procedures with } \\
\text { moderate results } \\
\text { (score } 3)\end{array}$ \\
\hline Segmental defects & 24 & 25 & $\begin{array}{l}<3 \mathrm{~cm}=19 \\
\geq 3 \mathrm{~cm}=6\end{array}$ & $\begin{array}{l}<3 \mathrm{~cm}=3 \\
\geq 3 \mathrm{~cm}=0\end{array}$ & $\begin{array}{l}<3 \mathrm{~cm}=15 \\
\geq 3 \mathrm{~cm}=2\end{array}$ & $\begin{array}{l}<3 \mathrm{~cm}=1 \\
\geq 3 \mathrm{~cm}=4\end{array}$ \\
\hline Cavitary defects & 42 & 42 & $\begin{array}{c}\text { Not } \\
\text { measured }\end{array}$ & 2 & 40 & 0 \\
\hline Total & 66 & 67 & - & 5 & 57 & 5 \\
\hline
\end{tabular}




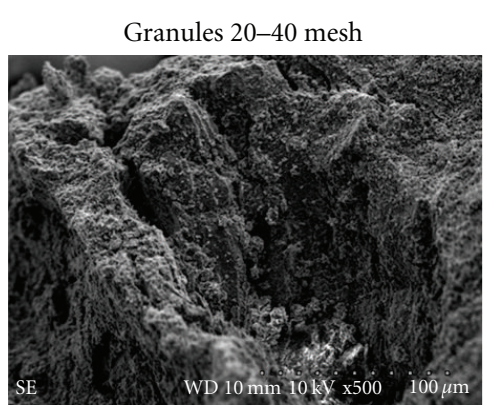

Granules 20-40 mesh

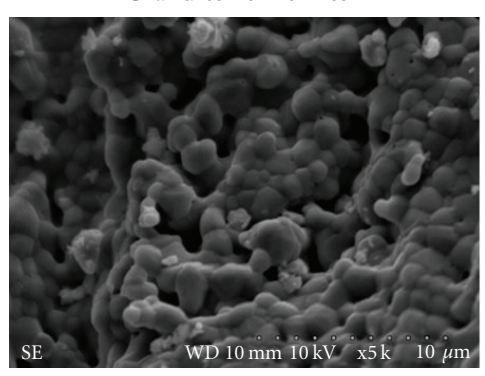

Granules 40-60 mesh

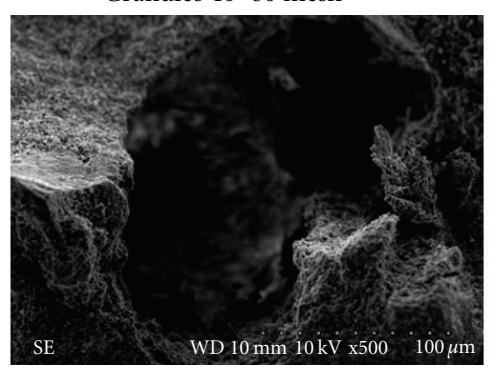

(a)

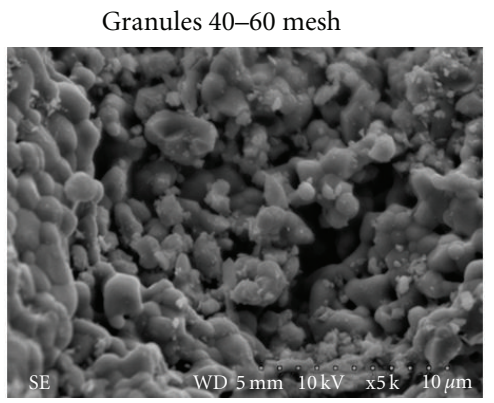

(b)
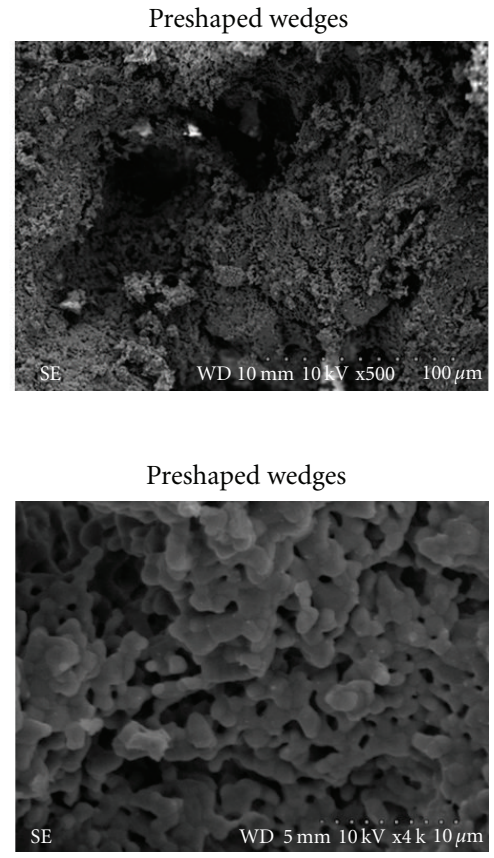

FIGURE 2: SEM images showing the physical structures of the granules 20-40 mesh, 40-60 mesh and preshaped wedge. The macroporosities (a) and microporosities (b) can be observed in all the samples.

good results for 40 procedures (score 4 ) and excellent results for 2 procedures (score 5) (Table 3 ).

Nineteen procedures were performed in segmental bone defects smaller than $3 \mathrm{~cm}$ in length and 6 procedures were performed in $3 \mathrm{~cm}$ defects or larger (Table 4 ).

Within the segmental defects that were smaller than $3 \mathrm{~cm}$ in length, three of them presented excellent results (score 5), 15 were classified as good results (score 4) and one had a moderate result (score 3 ). It is important to highlight, however, that in this particular case, the moderate result was not due to problems with the bioceramics but due to the shortening of the limb at the end of the treatment. As a consequence, the patient required a second surgical procedure, where the osteotomy for the limb lengthening was performed throughout the area that had been previously reconstructed with the bioceramics (Figure 3 ).

Of the 6 patients with bone defects equal or bigger than $3 \mathrm{~cm}$ in length, only two of them showed healing after the first surgery. One of them, however, received score 3 (moderate result) instead of 4 (good results) due to increased limitation of the knee movements. Three patients required a second surgical intervention, and one patient, with a defect of $11 \mathrm{~cm}$ in length, required a third procedure. Consequently, 2 procedures were classified as good (score 4) and 4 procedures, as moderate (score 3 ).

Only three patients out of 66 received BCP combined with autologous bone grafts in the first surgical intervention. These results were different for each of these 3. One patient had a cavitary bone defect that healed well, receiving score 5 , one patient, with a segmental bone defect of $4 \mathrm{~cm}$ in length, had a nonunion and required an additional surgical procedure using only BCP without autografts and received score 3 , and one patient with $11 \mathrm{~cm}$ length segmental defect required an additional surgery, receiving score 3 at the end of the treatment (Table 4).

None of the patients experienced poor results, that is, no integration of the bioceramics (Table 5) that could be either associated or not to an increased limitation or absence of movements.

\section{Discussion}

This study evaluated the efficacy of a biphasic calcium phosphate (BCP) bioceramics in the reconstruction of bone defects caused by trauma or associated with elective procedures such as prosthesis placement and revisions, arthrodesis, and osteotomies (called orthopedic defects) as well as in the reconstruction of cavitary and segmental bone defects.

A scale of different scores was used in order to measure the clinical and radiographic outcomes. Similar scoring scale has been used in a previous study [21]. We have shown that the BCP was successful in regenerating bone in all the cavitary and in segmental bone defects where the gaps were smaller than 3 centimetres in length. Most of these defects were also classified as orthopaedic defects. Segmental defects equal or larger than 3 centimetres in length, which were mostly caused by trauma, required special attention and eventually needed an additional surgical procedure to heal. In some of these patients, as the healing period was longer than for those with smaller defects, the substitution of the pins and nails used for fixation was required due to their 


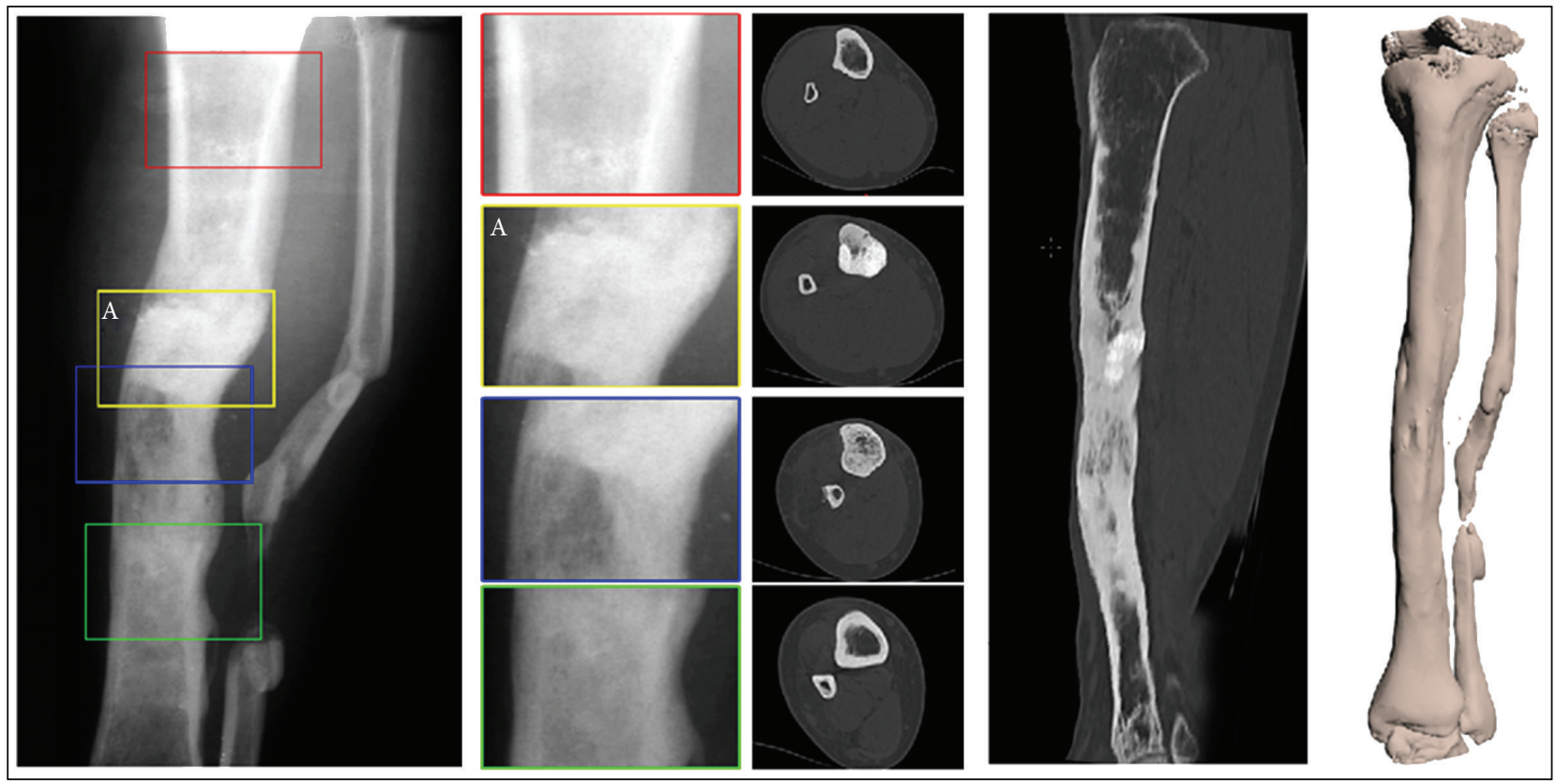

FIGURE 3: Bone lengthening in an area previously reconstructed with BCP. X-Ray and CT images of a tibia showing the zone reconstructed with $\mathrm{BCP}(\mathrm{A})$ and the new bone formed after osteotomy and bone lengthening, which was performed due to the shortening of the limb.

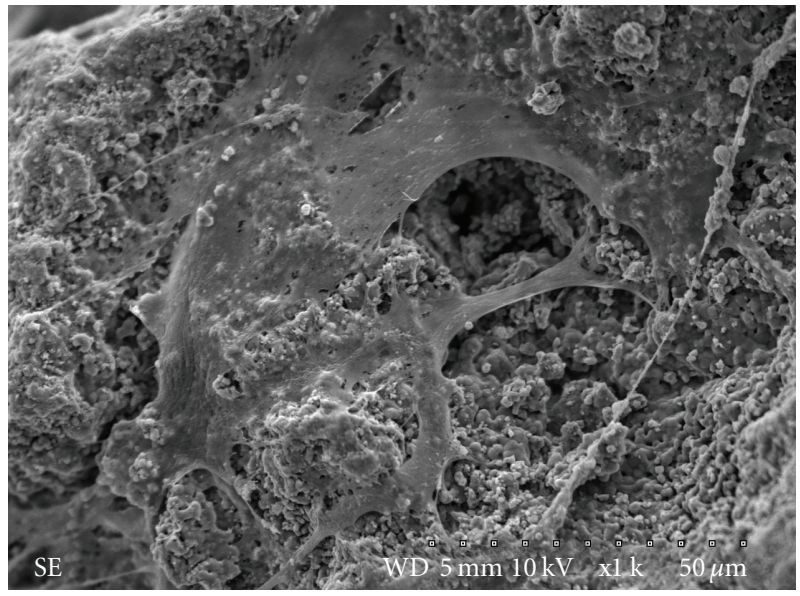

Figure 4: Human mesenchymal stem cells on the surface of a granule (40-60 mesh). SEM image shows stem cells spreading on the BCP surface and forming layers over the apertures of porous, after 7 days of culture.

movements and instability over time. None of the patients presented acute inflammatory reactions or infections. One of the factors that has been described as eliciting response of cells such as monocytes, which are among the first cells to contact the implant surface and to colonize the inflammatory site, is the ratio between the surface area of cells and the surface area of the biomaterial $[22,23]$. The ratio related to the surface area of cell/surface area of material equivalent to one has been shown to elicit the highest level of inflammatory cytokine production $[22,23]$. The granule sizes used in these clinical cases are much bigger than all cells, as shown by the SEM analysis (Figure 4). The chemical

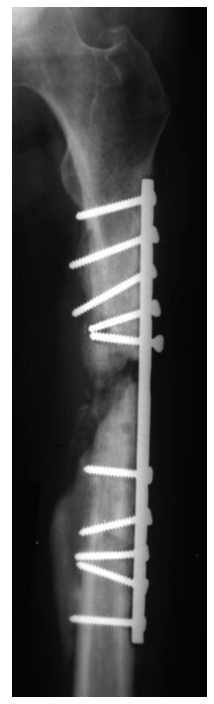

(a)

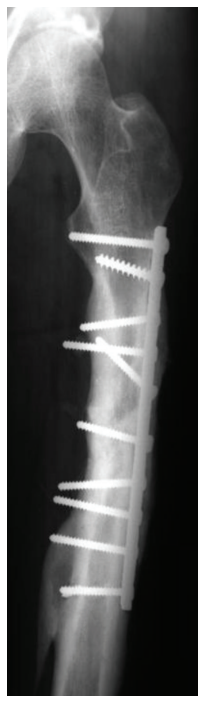

(b)
FIGURE 5: Reconstruction of a femoral bone defect with BCP. X-Ray images of a femur before (a) and after (b) reconstruction with the $\mathrm{BCP}$ and stabilized with internal fixation system, after trauma.

composition, topography, wettability, and surface energy of the biomaterial are other factors that will influence cell response $[24,25]$.

Our radiographic analysis showed a higher radiopacity at the implant site even in the long-term evaluation (Figures 3,5 , and 6). This is in agreement with the study reported by Rouvillain et al. [26] that showed the same image 


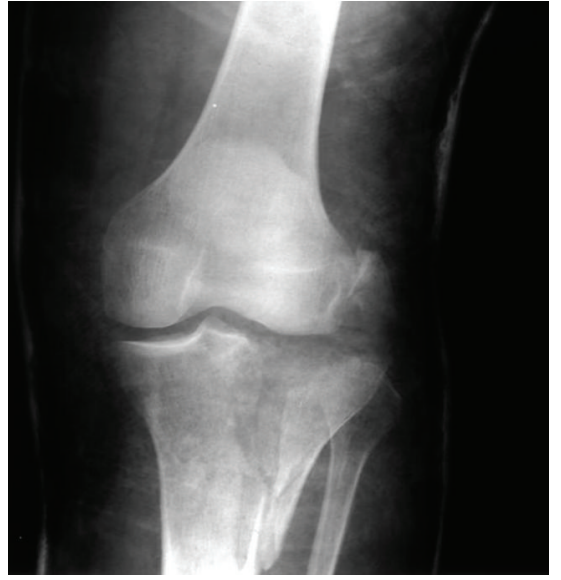

(a)

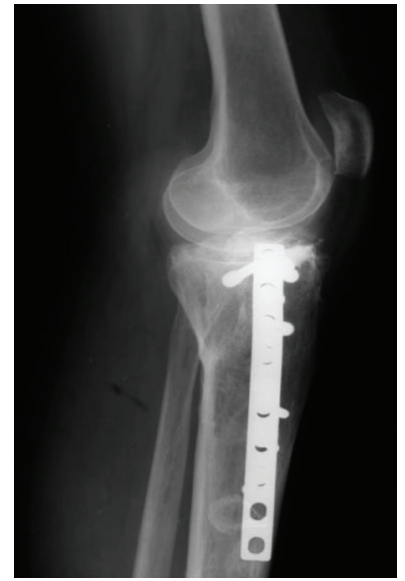

(b)

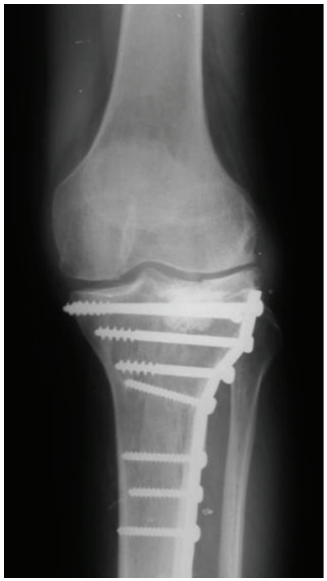

(c)

FIgURE 6: A tibial bone defect reconstructed with BCP. X-Ray image of a tibial fracture (a) with the lateral (b) and anterior view (c) after 2 years of reconstruction using the BCP.

TABle 4: Lengths of the segmental bone defects. Nineteen procedures were performed in defects smaller than $3 \mathrm{~cm}$ in length and six, in defects equal or larger than $3 \mathrm{~cm}$. The final scores (combination of clinical and radiographic analysis) are described. One patient received bilateral intervention. The majority of good and excellent results (scores 4 and 5) were observed in patients with defects equal or smaller than $3 \mathrm{~cm}$ in length.

\begin{tabular}{|c|c|c|c|}
\hline Procedure ID & Length of the defect & Bone affected & Final score \\
\hline 1 & 11 & Femur & 3 \\
\hline 3 & 2 & Femur & 4 \\
\hline 13 & 3 & Femur & 3 \\
\hline 14 & 1.5 & Femur & 4 \\
\hline 17 & 1 & Tibia & 4 \\
\hline 22 & 1 & Clavicle & 5 \\
\hline 26 & 3.5 & Femur & 4 \\
\hline 27 & 0.5 & Clavicle & 5 \\
\hline 35 & 2.5 & Forearm & 4 \\
\hline 36 & 1 & Forearm & 4 \\
\hline 37 & 0.5 & Femur & 4 \\
\hline 40 & 1 & Femur & 4 \\
\hline 41 & 5 & Femur & 3 \\
\hline 43 & 1 & Femur & 4 \\
\hline 45 & 0.5 & Clavicle & 5 \\
\hline 46 & 1.5 & Humerus & 4 \\
\hline 47 & 2 & Tibia & 3 \\
\hline 48 & 4 & Tibia & 3 \\
\hline 49 & 1.5 & Radius & 4 \\
\hline 50 & 2.5 & Humerus & 4 \\
\hline 51 & 3 & Humerus & 4 \\
\hline 54 & 2 & Femur & 4 \\
\hline 55 & 2.5 & Humerus & 4 \\
\hline 62 & 2 & Femur & 4 \\
\hline 63 & 1 & Femur & 4 \\
\hline
\end{tabular}

characteristic even after 18 months of the implantation of $\mathrm{BCP}(60 \% \mathrm{HA} / 40 \% \beta$-TCP) wedges in high tibial valgisation
TABle 5: Results of the radiographic analysis according to the etiology of the bone defects. Most of the patients received score 2, corresponding to the integration of the bioceramics after the first surgical procedure.

\begin{tabular}{lccc}
\hline $\begin{array}{l}\text { Etiology of the } \\
\text { bone defects }\end{array}$ & \multicolumn{4}{l}{$\begin{array}{l}\text { Number of procedures according to the } \\
\text { radiographic scores }\end{array}$} \\
& Score 0 & Score 1 & Score 2 \\
\hline Traumatic defects & - & 4 & 30 \\
Orthopedic defects & - & - & 33 \\
\hline
\end{tabular}

osteotomies. These authors gave evidences of a resorption rate corresponding to more than $60 \%$ of the bioceramics after 2 years and demonstrated that the high radiopacity was due to the greater mineral concentration and the composite formed by the new bone tissue and the residual granules and not due to the nonresorption of the biomaterial [26]. Our good results are in agreement with those reported by others [27].

Since the first successful clinical application of commercial calcium phosphate bioceramics in the early 1970s, modifications on their properties gave rise to alternatives with improved biological and mechanical properties [7, 9, $10,17,28-30]$.

The BCP used in this study consisted of $65 \%$ of HA and $35 \%$ of $\beta$-TCP and belongs to the third generation of biomaterials, namely, those having appropriate micro- and macroporosities, good mechanical properties, and promoting not only bone substitution but also bone regeneration [9]. An animal study showed that such bioceramics, in the granular form (40-60 mesh) promoted a bone mass gain up to 4 -fold the initial volume used [20].

The nature, timing and progression of the bone regeneration, was shown to be influenced not only by the bone physiology, biomechanical properties at the site of the lesion, age, and intrinsic conditions of the patient but also by the chemical composition and physical structure of bone graft substitute, which will directly influence the migration and proliferation of the host cells [7, 10, 15, 18, 19, 31-33]. 
For a biomaterial to function as a good scaffold, it must not be prematurely resorbed before the new bone formation occurs. For this reason, highly soluble compounds, such as calcium sulphate, calcium carbonate, dicalcium phosphate dihydrate, octacalcium phosphate, and beta-tricalcium phosphate alone, may not be suitable materials for the reconstruction of major bone defects in humans, even if in vitro cell response to these calcium phosphate materials is positive. Bioceramics with rapid resorption or dissolution rate promotes an important change of the local $\mathrm{pH}$ due to the high levels of calcium ions released, leading to a mild inflammatory process and/or to a fibrous encapsulation of the material $[31,34]$ resulting in an unsuccessful bone regeneration.

Thus, in the time-dependent process of bone formation, the degradation rate is a key point for the clinical success, mainly when larger defects are being treated. Indubitably the use of BCP with different ratios of low soluble component (HA) and a highly soluble phase ( $\beta$-TCP) is an option to tailor the degradation kinetics of calcium bioceramics from a few weeks to a few years $[5,7,10,11,15]$.

Some calcium phosphate $(\mathrm{CaP})$ bioceramics with different physical structures (including the size and density of porosity) and chemical composition have been used alone or mixed with adjuvants of bone healing (e.g., fibrin sealant, platelet-rich plasma and stem cells) in several clinical situations with good results [35-43]. However, in most of these cases, the bioceramics were applied in relatively small bone defects.

Different results were obtained from the 3 patients who were treated with a combination of $\mathrm{BCP} /$ autografts. Considering that this number of patients is very low and the results are not consistent, no conclusion can be made about the possible benefits of combining autografts with BCP. Further studies still must be performed in order to collect evidences that support the real advantages of such strategy.

Another crucial point that must be taken into account for a successful clinical treatment is the correct preparation of the surgical site. All the surgical technique principles that are indicated for the autologous bone grafting must be applied for the bioceramics implantation. Indeed, avoiding infected areas, eliminating all the granular tissues and fibrosis at the surgical site, and impacting the biomaterial where healthy and bloody bone extremities are observed are crucial steps.

\section{Conclusions}

This study showed clinical evidences of the efficacy of the micro- and macroporous biphasic calcium phosphate (BCP) bioceramics with $65 \mathrm{HA} / 35 \beta$-TCP ratio, in the reconstruction of not only small but also large bone defects in humans. Results from this study suggest that such material can be used in load-bearing areas and represents a safe and predictable alternative for autografts and allografts. In case of segmental bone defects equal or larger than $3 \mathrm{~cm}$ in length, the association of BCP scaffolds, such as the ones used in this study, with bioactive molecules or stem cells may be considered.
Knowledge of the bioceramics properties and application of appropriate surgical techniques are critical aspects for good clinical outcomes.

\section{Acknowledgment}

The authors would like to thank Dr José Laredo Filho (in memoriam) for his insightful comments during the elaboration of this study and for his dedication to the development of orthopedic surgery.

\section{References}

[1] R. Z. LeGeros, "Calcium phosphate materials in restorative dentistry: a review," Advances in Dental Research, vol. 2, no. 1, pp. 164-180, 1988.

[2] E. B. Nery, R. Z. LeGeros, K. L. Lynch, and K. Lee, "Tissue response to biphasic calcium phosphate ceramic with different ratios of HA/beta TCP in periodontal osseous defects," Journal of Periodontology, vol. 63, no. 9, pp. 729-735, 1992.

[3] R. Z. LeGeros, G. Daculsi, E. Nery, K. Lynch, and B. Kerebel, "In vivo transformation of biphasic calcium phosphates of varying $\beta$-TCP:HA ratios: ultrastructural characterization," in Proceedings of the 3rd World Biomaterials Congress, 1988.

[4] R. Z. LeGeros, "Variability of $\beta$-TCP-HAP ratios in sintered "apatites"', in Proceedings of the Annual Meeting of the Rochester Section of the American Association for Dental Research (AADR '86), Washington, DC, USA, 1986.

[5] R. Z. LeGeros and G. Daculsi, "In vivo transformation of biphasic calcium phosphate ceramics: ultrastructural and physico-chemical characterizations," in Handbook of Bioactive Ceramics, T. Yamamuro and J. Wilson-Hench, Eds., vol. 11, pp. 17-28, CRC Press, Boca Raton, Fla, USA, 1997.

[6] G. Daculsi, N. Passuti, S. Martin, C. Deudon, R. Z. Legeros, and S. Raher, "Macroporous calcium phosphate ceramic for long bone surgery in humans and dogs. Clinical and histological study," Journal of Biomedical Materials Research, vol. 24, no. 3, pp. 379-396, 1990.

[7] G. Daculsi, O. Laboux, O. Malard, and P. Weiss, "Current state of the art of biphasic calcium phosphate bioceramics," Journal of Materials Science: Materials in Medicine, vol. 14, no. 3, pp. 195-200, 2003.

[8] G. Daculsi and R. LeGeros, "Biphasic calcium phosphate (BCP) bioceramics: chemical, physical and biological properties," Encyclopedia of Biomaterials and Biomedical Engineering, pp. 1-1, 2006.

[9] D. Arcos, I. Izquierdo-Barba, and M. Vallet-Regí, "Promising trends of bioceramics in the biomaterials field," Journal of Materials Science: Materials in Medicine, vol. 20, no. 2, pp. 447455, 2009.

[10] R. Z. Legeros, S. Lin, R. Rohanizadeh, D. Mijares, and J. P. Legeros, "Biphasic calcium phosphate bioceramics: preparation, properties and applications," Journal of Materials Science: Materials in Medicine, vol. 14, no. 3, pp. 201-209, 2003.

[11] R. Z. Legeros, "Biodegradation and bioresorption of calcium phosphate ceramics," Clinical Materials, vol. 14, no. 1, pp. 65$88,1993$.

[12] O. Gauthier, J. M. Bouler, E. Aguado, R. Z. Legeros, P. Pilet, and G. Daculsi, "Elaboration conditions influence physicochemical properties and in vivo bioactivity of macroporous biphasic calcium phosphate ceramics," Journal of Materials Science: Materials in Medicine, vol. 10, no. 4, pp. 199-204, 1999. 
[13] Y. R. Duan, Z. R. Zhang, C. Y. Wang, J. Y. Chen, and X. D. Zhang, "Dynamic study of calcium phosphate formation on porous HA/TCP ceramics," Journal of Materials Science: Materials in Medicine, vol. 15, no. 11, pp. 1205-1211, 2004.

[14] R. Xin, Y. Leng, J. Chen, and Q. Zhang, "A comparative study of calcium phosphate formation on bioceramics in vitro and in vivo," Biomaterials, vol. 26, no. 33, pp. 6477-6486, 2005.

[15] F. Barrère, C. A. van Blitterswijk, and K. de Groot, "Bone regeneration: molecular and cellular interactions with calcium phosphate ceramics," International Journal of Nanomedicine, vol. 1, no. 3, pp. 317-332, 2006.

[16] F. Barrère, C. A. van Blitterswijk, and K. de Groot, "Bone regeneration: molecular and cellular interactions with calcium phosphate ceramics," International Journal of Nanomedicine, vol. 1, no. 3, pp. 317-332, 2006.

[17] H. Yuan, C. A. van Blitterswijk, K. De Groot, and J. D. De Bruijn, "A comparison of bone formation in biphasic calcium phosphate (BCP) and hydroxyapatite (HA) implanted in muscle and bone of dogs at different time periods," Journal of Biomedical Materials Research A, vol. 78, no. 1, pp. 139-147, 2006.

[18] W. G. De Long Jr., T. A. Einhorn, K. Koval et al., "Bone grafts and bone graft substitutes in orthopaedic trauma surgery," The Journal of Bone and Joint Surgery. American Volume, vol. 89, no. 3, pp. 649-658, 2007.

[19] Z. Zyman, V. Glushko, N. Dedukh, S. Malyshkina, and N. Ashukina, "Porous calcium phosphate ceramic granules and their behaviour in differently loaded areas of skeleton," Journal of Materials Science: Materials in Medicine, vol. 19, no. 5, pp. 2197-2205, 2008.

[20] S. E. Lobo, F. H. L. Wykrota, A. C. M. B. Oliveira, I. Kerkis, G. B. Mahecha, and H. J. Alves, "Quantification of bone mass gain in response to the application of biphasic bioceramics and platelet concentrate in critical-size bone defects," Journal of Materials Science: Materials in Medicine, vol. 20, no. 5, pp. 1137-1147, 2009.

[21] L. P. D’Andrea, R. R. Betz, L. G. Lenke et al., "Do radiographic parameters correlate with clinical outcomes in adolescent idiopathic scoliosis?" Spine, vol. 25, no. 14, pp. 1795-1802, 2000.

[22] A. S. Shanbhag, J. J. Jacobs, J. Black, J. O. Galante, and T. T. Glant, "Macrophage/particle interactions: effect of size, composition and surface area," Journal of Biomedical Materials Research, vol. 28, no. 1, pp. 81-90, 1994.

[23] P. Laquerriere, A. Grandjean-Laquerriere, E. Jallot, G. Balossier, P. Frayssinet, and M. Guenounou, "Importance of hydroxyapatite particles characteristics on cytokines production by human monocytes in vitro," Biomaterials, vol. 24, no. 16, pp. 2739-2747, 2003.

[24] J. Y. Lim and H. J. Donahue, "Biomaterial characteristics important to skeletal tissue engineering," Journal of Musculoskeletal Neuronal Interactions, vol. 4, no. 4, pp. 396-398, 2004.

[25] J. Y. Lim, A. D. Dreiss, Z. Zhou et al., "The regulation of integrin-mediated osteoblast focal adhesion and focal adhesion kinase expression by nanoscale topography," Biomaterials, vol. 28, no. 10, pp. 1787-1797, 2007.

[26] J. L. Rouvillain, F. Lavallé, H. Pascal-Mousselard, Y. Catonné, and G. Daculsi, "Clinical, radiological and histological evaluation of biphasic calcium phosphate bioceramic wedges filling medial high tibial valgisation osteotomies," The Knee, vol. 16, no. 5, pp. 392-397, 2009.

[27] M. Ozalay, O. Sahin, S. Akpinar, G. Ozkoc, M. Cinar, and N. Cesur, "Remodeling potentials of biphasic calcium phosphate granules in open wedge high tibial osteotomy," Archives of
Orthopaedic and Trauma Surgery, vol. 129, no. 6, pp. 747-752, 2009.

[28] N. Rochet, A. Loubat, J. P. Laugier et al., "Modification of gene expression induced in human osteogenic and osteosarcoma cells by culture on a biphasic calcium phosphate bone substitute," Bone, vol. 32, no. 6, pp. 602-610, 2003.

[29] F. Ye, X. Lu, B. Lu et al., "A long-term evaluation of osteoinductive HA/ $\beta$-TCP ceramics in vivo: 4.5 Years study in pigs," Journal of Materials Science: Materials in Medicine, vol. 18, no. 11, pp. 2173-2178, 2007.

[30] L. L. Wykrota, F. H. L. Wykrota, and C. A. Garrido, "Longterm regeneration in large human defect using calciumphosphate particulate," in Bone Engineering, J. E. Davies, Ed., pp. 516-524, Em2 Inc, Toronto, Canada, 2000.

[31] K. A. Hing, L. F. Wilson, and T. Buckland, "Comparative performance of three ceramic bone graft substitutes," Spine Journal, vol. 7, no. 4, pp. 475-490, 2007.

[32] D. J. Hak, "The use of osteoconductive bone graft substitutes in orthopaedic trauma," Journal of the American Academy of Orthopaedic Surgeons, vol. 15, no. 9, pp. 525-536, 2007.

[33] U. Ripamonti, "Osteoinduction in porous hydroxyapatite implanted in heterotopic sites of different animal models," Biomaterials, vol. 17, no. 1, pp. 31-35, 1996.

[34] K. A. Hing, I. R. Gibson, P. A. Revell, S. M. Best, and W. Bonfield, "Influence of phase purity on the in vivo response to hydroxyapatite," Key Engineering Materials, vol. 192-195, pp. 373-376, 2001.

[35] A. O. Ransford, T. Morley, M. A. Edgar et al., "Synthetic porous ceramic compared with autograft in scoliosis surgery," The Journal of Bone and Joint Surgery. British Volume, vol. 80, no. 1, pp. 13-18, 1998.

[36] R. Cavagna, G. Daculsi, and J. M. Bouler, "Macroporous calcium phosphate ceramic: a prospective study of 106 cases in lumbar spinal fusion," Journal of Long-Term Effects of Medical Implants, vol. 9, no. 4, pp. 403-412, 1999.

[37] C. Nich, P. Bizot, R. Nizard, and L. Sedel, "Femoral reconstruction with macroporous biphasic calcium phosphate ceramic in revision hip replacement," Key Engineering Materials, vol. 240242, pp. 853-856, 2003.

[38] O. S. Schindler, S. R. Cannon, T. W. Briggs, and G. W. Blunn, "Composite ceramic bone graft substitute in the treatment of locally aggressive benign bone tumours," Journal of Orthopaedic Surgery, vol. 16, no. 1, pp. 66-74, 2008.

[39] T. Yamamoto, T. Onga, T. Marui, and K. Mizuno, "Use of hydroxyapatite to fill cavities after excision of benign bone tumours," The Journal of Bone and Joint Surgery. British Volume, vol. 82, no. 8, pp. 1117-1120, 2000.

[40] M. Bagot D’Arc and G. Daculsi, "Micro macroporous biphasic ceramics and fibrin sealant as a moldable material for bone reconstruction in chronic otitis media surgery. A 15 years experience," Journal of Materials Science: Materials in Medicine, vol. 14, no. 3, pp. 229-233, 2003.

[41] C. Nich and L. Sedel, "Bone substitution in revision hip replacement," International Orthopaedics, vol. 30, no. 6, pp. 525-531, 2006.

[42] M. Marcacci, E. Kon, V. Moukhachev et al., "Stem cells associated with macroporous bioceramics for long bone repair: 6- To 7-year outcome of a pilot clinical study," Tissue Engineering, vol. 13, no. 5, pp. 947-955, 2007.

[43] S. Paderni, S. Terzi, and L. Amendola, "Major bone treatment with an osteoconductive bone substitute," Musculoskeletal Surgery, vol. 93, no. 2, pp. 89-96, 2009. 

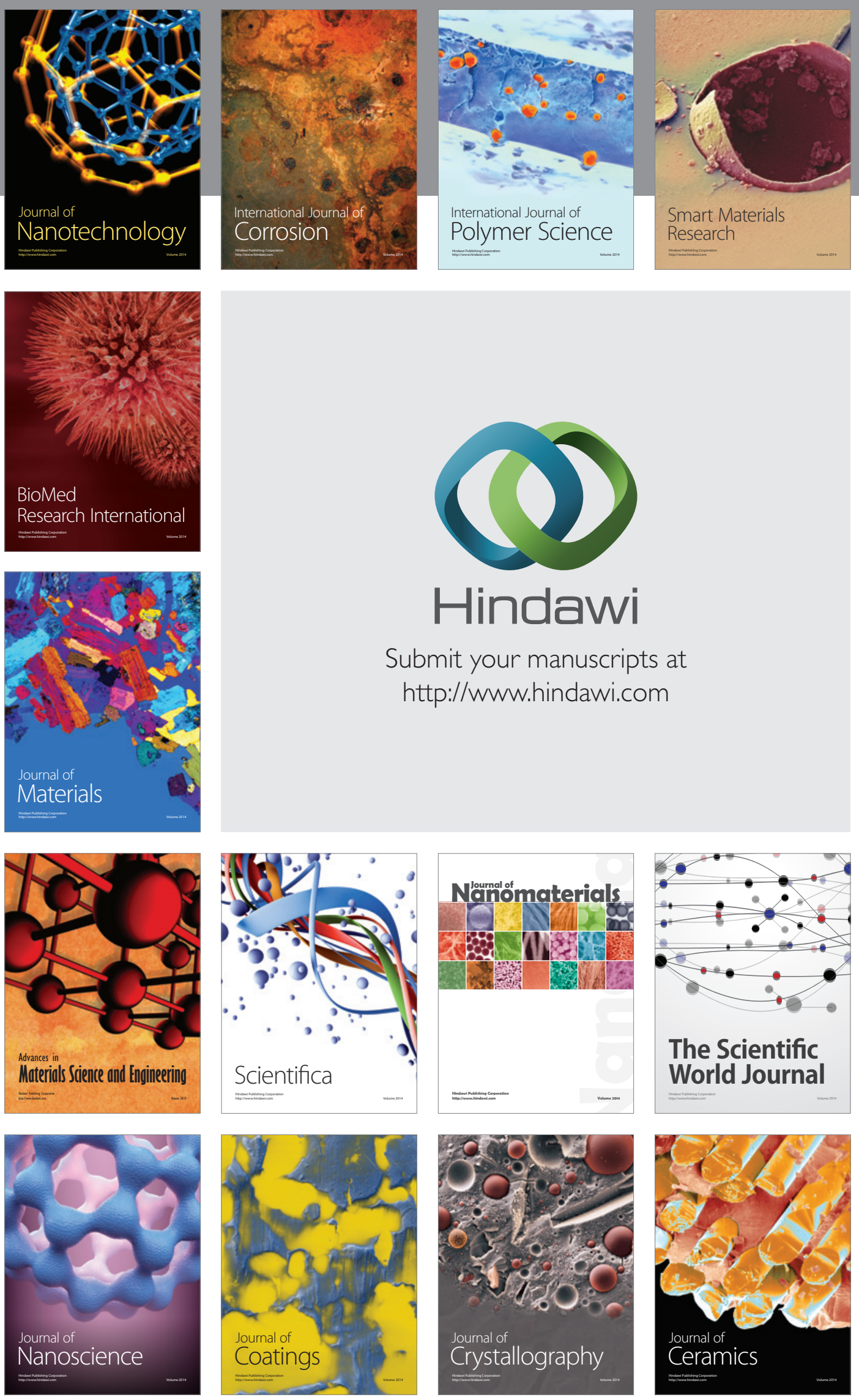

The Scientific World Journal

Submit your manuscripts at

http://www.hindawi.com

\section{World Journal}

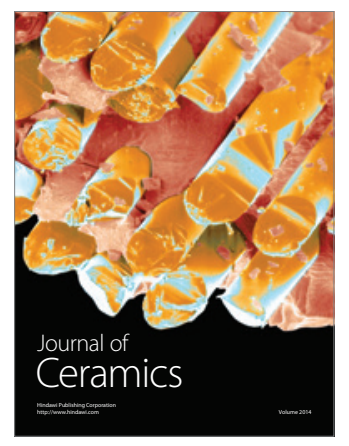

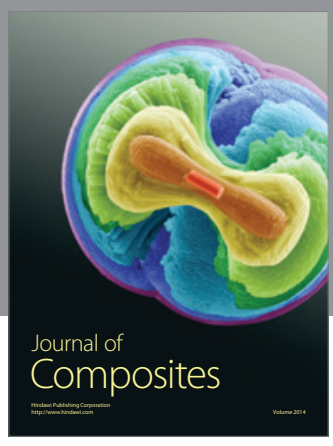
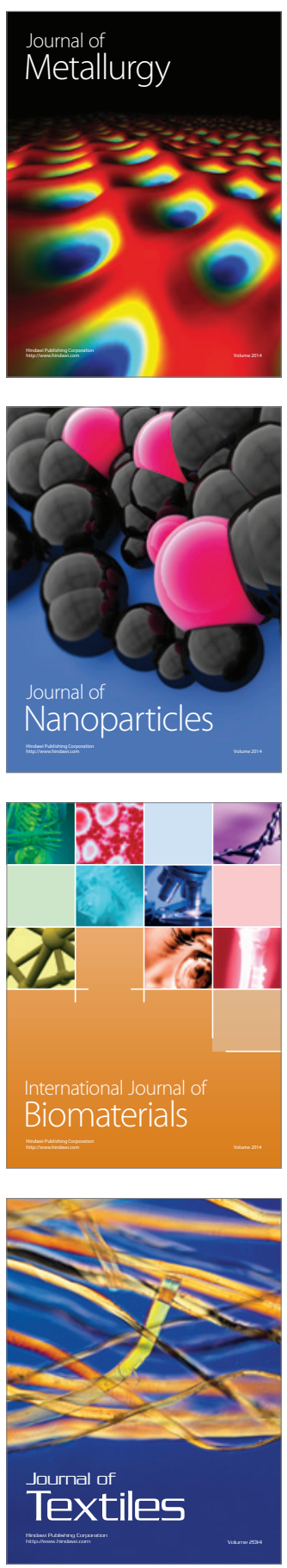